\title{
Analisis Awal Potensi Renewable Energy di Bawah Jembatan Aur Duri II Jambi
}

\author{
S. Umar Djufri \\ Jurusan Teknik Listrik, Fakultas Teknik, Universitas Batanghari \\ ${ }^{*}$ Corresponding author, e-mail: umarjufri01@yahoo.co.id
}

\begin{abstract}
Abstrak
Kota Jambi merupakan daerah yang dibentangi sungai batanghari, kajian mengenai pemanfaatan terhadap enegi listrik terbarukan khususnya tenaga air melalui anak sungai perlu di pertimbangkan untuk perencanan Pembangkit Listrik Tenaga Mikro Hidro (PLTMH). Kondisi air yang dapat dimanfaatkan sebagai sumberdaya (resources) penghasil listrik memiliki kapasitas aliran dan ketinggian tertentu dari sistem saluran airnya. Masalah utama dalam pembangkitan listrik tenaga air adalah ketersediaan debit air sungai sebagai energi penggerak pembangkit. Oleh karenanya dibutuhkan teknik tertentu untuk memprediksi potensi aliran air sungai pada sepanjang waktu atau debit andalan sungai yang dapat digunakan untuk energi pembangkit listrik tenaga mikro hidro, tidak terjadinya hujan dengan waktu yang lama serta kondisi daerah aliran sungai (DAS) yang kritis dapat menyebabkan aliran air sungai menjadi kecil bahkan menjadi kering. Pengukuran debit sungai secara manual pada waktu tertentu hanya dapat merepresentasi volume debit sungai pada saat dilakukan pengukuran. Perubahan yang terjadi akibat terjadinya hujan pada waktu berikutnya, atau penurunan debit sungai karena simpanan air tanah yang mengecil, tidak dapat terpantau dengan baik maka perlu direncanakan debit yang kontiniu untuk kapasitas putaran turbin generator dengan memperhitungkan kapasitas listrik dari generator yang dapat dibangkitkan secara optimal
\end{abstract}

Kata Kunci : pembangkit listrik, mikrohidro, Perencanaan, Sungai

\begin{abstract}
The city of Jambi is dibentangi River batanghari, study on utilization of renewable electricity in particular an against water power through Streams need to be consider for perencanan Micro Hydro power plant (PLTMH). Water conditions that can be utilized as a resource (resources) electric generator has a capacity of flow and elevation of water channel system. The main problems in hydropower generation is the availability of water of the river discharge as energy for propulsion power plant. Therefore it takes a specific technique to predict the potential flow of river water on all the time or signature debit River that can be used for energy micro hydro power plant, not the onset of rain with a long time as well as the condition of watersheds (DAS) that can cause critical flow of river water into small even dried up. River discharge measurements manually at any given time can only represent the volume of discharge of the River at the time of measurement is performed. Changes that occur due to the onset of rain in the next time, or decrease in discharge of the River because the groundwater deposits shrink, can not be observed with either it needs to be planned debit kontiniu for turbine generator round capacity taking into account the capacity of electricity from generators that can be optimally raised
\end{abstract}

Keywords: electric generators, micro hydro, planning, River

\section{PENDAHULUAN}

Energi Listrik merupakan kebutuhan yang sangat vital karena pemanfaatannya dapat dirasakan oleh seluruh masyarakat khususnya wilayah jambi. Dengan kondisi topografi yang memiliki banyak aliran sungai jambi merupakan wilayah yang potensial untuk membangun Pembangkit Listrik Tenaga
Mikrohidro (PLTMH) pada kondisi ini sangat memungkin untuk mengoptimalkan potensi tersebut. Dari data BMG Provinsi Jambi didapat kecepatan angin rata-rata sekitar $4 \mathrm{~m} / \mathrm{s}-11 \mathrm{~m} / \mathrm{s}$ pertahun sehingga Pembangkit Listrik Tenaga Bayu (PLTB) dapat optimalkan guna dikombinasi (Hybrid) dengan PLTMH, dengan adanya potensi tersebut khususnya sekitar wilayah daerah jembatan Aur Duri II jambi 
dapat dikembangkan pembangkit listrik dengan kapasitas dibawah $10 \mathrm{KW}$ pembangkit tenaga (hybrid). Areal jembatan aurduri II mempunyai lebar sungai $\pm 450 \mathrm{~m}$ disepanjang jalan jembatan yang membentang dari hulu ke hilir panjang jembatan yang merupakan jalur akses penting yang menghubungkan kota jambi dengan kabupaten diluar jambi (muaro jambi dan sabak)

Pada peneitian ini akan dikaji analisis spasial potensi energi listrik yang dapat digunakan sebagai kebutuhan penerangan disekitar jembatan Aur Duri II kota Jambi. Analisis yang dikaji meliputi data kecepatan angin dibawah jembatan dan data beda tinggi suatu aliran sungai (head) dan debit aliran sungai untuk lokasi yang paling potensial untuk perencanaan pembangunan pembangkit tenaga hybrid. Data tersebut nantinya akan disesuikan dengan kapasitas dari generator pembangkit Sehingga pemanfaatan energi listrik dapat digunakan sebagai fasilitas penerangan jalan disekitar jembatan Aur Duri II seperti ditunujukan gambar 1 dibawah.

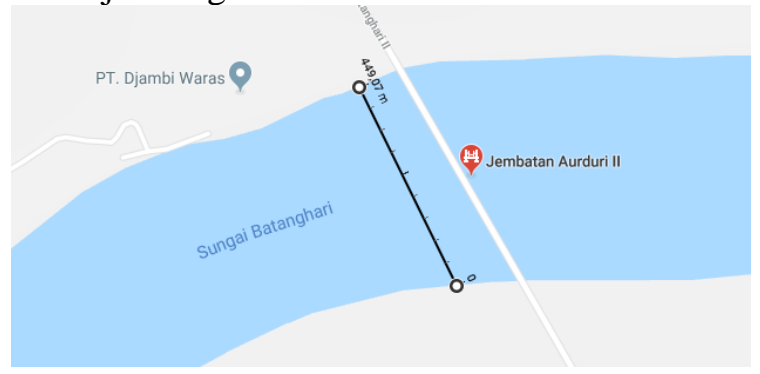

\section{Gambar 1. Jembatan Aur Duri II (sumber:google maps)}

\section{TINJAUAN PUSTAKA}

\subsection{PLTB (Pembangkit Listrik Tenaga Bayu}

Angin terjadi karena adanya perbedaan suhu antara udara panas dan udara dingin yang menyebabkan terjadinya suatu perputaran udara berupa perpindahan udara. Di daerah khatulistiwa, udaranya menjadi panas mengembang dan menjadi ringan, naik keatas dan bergerak ke daerah yang lebih dingin. sebaliknya daerah kutub yang dingin, udaranya menjadi dingin dan turun ke bawah. Sehingga terjadilah suatu perputaran udara berupa perpindahan udara dari kutub utara ke garis khatulistiwa menyusuri permukaan bumi dan sebaliknya suatu perpindahan udara dari garis katulistiwa kembali ke kutub utara, melalui lapisan udara yang lebih tinggi.[6]

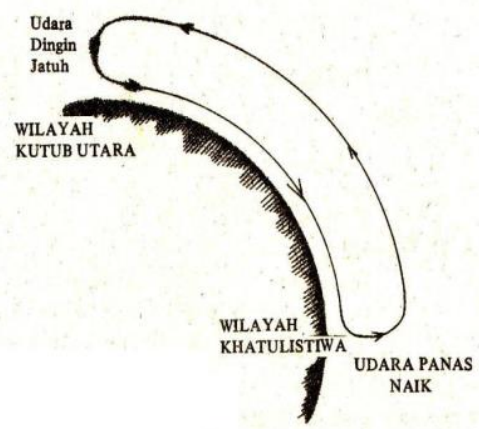

Gambar 2. Skema terjadinya angin[1]

Sebagaimana diketahui menurut fisika klasik energi kinetik dari sebuah benda dengan massa (m) dan kecepatan (v) adalah :

$$
\mathrm{E}=0,5 \mathrm{~m} \cdot \mathrm{v}^{2}
$$

dengan ketentuan, kecepatan (v) tidak mendekati kecepatan cahaya. Rumus itu berlaku juga untuk angin, yang merupakan udara yang bergerak.

Untuk keperluan praktis sering dipakai rumus pendekatan berikut:

$$
\begin{aligned}
& \mathbf{P}=\mathbf{k} \cdot \mathbf{A} \cdot \mathbf{v}^{3} \\
& \text { dimana : } \\
& \mathrm{P}=\text { daya }(\mathrm{kW}) \text {; } \\
& \mathrm{k}=\text { suatu konstanta }\left(1,37.10^{-5}\right) \text {; } \\
& \mathrm{A}=\text { luas sudu kipas }\left(\mathrm{m}^{2}\right) \text {; } \\
& \mathrm{v}=\text { kecepatan angin }(\mathrm{km} / \mathrm{jam}) \text {. }
\end{aligned}
$$

pada persamaan (2) besaran $\mathrm{k}$ dan $\mathrm{A}$ sebagai konstanta, pada prinsipnya besaran $\mathrm{k}$ mewakili suatu faktor seperti geseran dan efesiensi sistem yang juga bergantung pada kecepatan angin (v), luas penampangsudu (A) bergantung dari bentuk sudu yang dapat diprediksi. Untuk mendapatkan daya efektif dari angin yang mungkin dihasilkan dari suatu kincir angin adalah:

$$
\mathbf{E a}=\text { 0,5.C.p.A. } \mathbf{v}^{3}
$$

$$
\begin{aligned}
& \text { dimana : } \\
& \begin{array}{l}
\text { Ea = Daya efektif yang dihasilkan kincir } \\
\text { angin (watt) }
\end{array} \\
& \mathrm{C}=\text { Konstanta Bets yaitu konstanta } \\
& \text { harganya } 16 / 27(59,3 \%) \text { - batas } \\
& \text { Betz } \quad \text { han }
\end{aligned}
$$




$$
\begin{aligned}
& \mathrm{A}=\text { Luas sapuan Rotor }\left(\text { dianggap } 1 \mathrm{~m}^{2}\right) \\
& \mathrm{v}=\text { Kecepatan angin }(\mathrm{m} / \mathrm{dt}) \\
& \rho=\text { Kerapatan Udara diformulasikan } \\
& \text { sebagai berikut : }
\end{aligned}
$$

$$
\rho=\mathbf{P} /(\mathbf{R} . \mathbf{T})
$$

$$
\text { dimana : }
$$

$\rho=$ kerapatan udara $\left(\mathrm{kg} / \mathrm{m}^{3}\right)$

$\mathrm{P}=$ tekanan udara (pascal)

$\mathrm{R}=$ Konstanta gas $287,05 \mathrm{~J} / \mathrm{Kg} . \mathrm{K}$

$\mathrm{T}=$ Temperatur (Kelvin)

selanjutnya konversi energi angin menjadi energi listrik dapat menggunakan formula :

$$
\left(\mathbf{P}_{\text {syst }} / \mathrm{A}\right)=\mathbf{0 , 1 4 5 4} . \mathbf{v}^{3}\left(\text { watt } / \mathbf{m}^{2}\right)
$$

Selain dari data yang ditunjukan gambar sebelumnya, penentuan kecepatan angin suatu daerah dapat juga dilakukan dengan menggunakan metode probalistik distribusi Weibull dalam mengolah kumpulan data hasil survey seperti yang diperlihatkan pada gambar 3 dibawah.

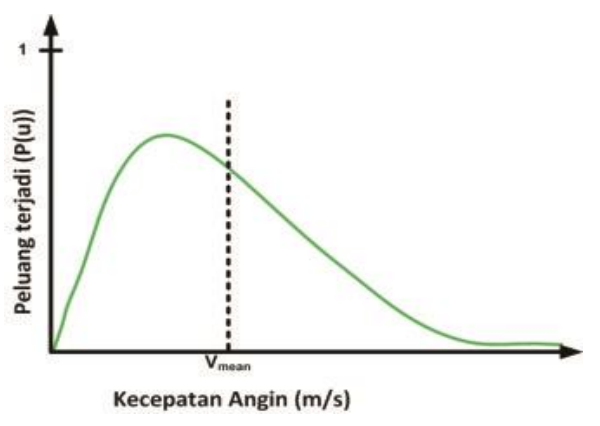

Gambar 3. Karakteristik Angin[4]

Karakteristik angin pada kondisi tertentu harus dapat dilakukan pengukuran secara berkala untuk didapat kecepatan rata - rata angin, sehingga daya mekanik dari turbin angin seperti ditunjukan gambar 4 dibawah dapat dioptimalkan.

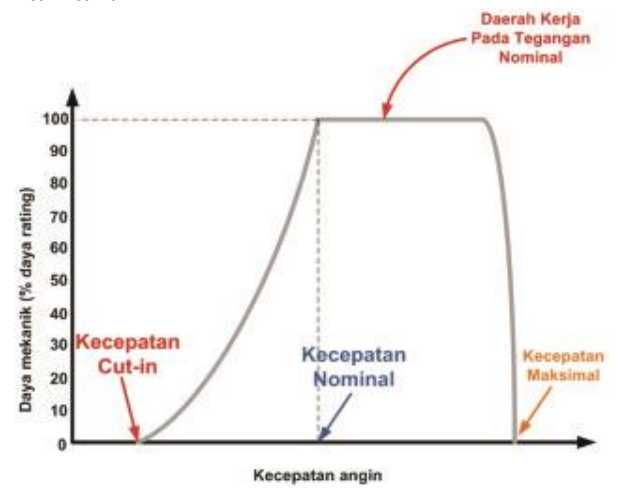

\author{
Gambar 4. Karakteristik Kerja Daya \\ Mekanik Turbin Angin[4]
}

3

Angindapat bergerak secara horizontal maupun vertikal dengan kecepatan yang dinamis dan fluktuatif. Pergerakan angin secara horizontal dinamakan adveksi, sedangkan pergerakan secara vertikal dinamakan konveksi. Dalam pemanfaatan energi angin diperlukan data atau informasi mengenai potensi energi angin aktual yang tersedia di lokasi pemasangan dan pemanfaatan sesuai kebutuhan di lokasi tersebut.

\subsection{PLTMH (Pembangkit Listrik Tenaga Mikrohydro)}

Pembangkit listrik mikrohidro adalah pembangkit listrik yang menggunakan energi air (aliran air anak sungai) sebagai energi penggerak generator pembangkit listriknya. Kondisi air yang dapat dimanfaatkan sebagai sumberdaya (resources) penghasil listrik memiliki kapasitas aliran dan ketinggian tertentu dari sistem saluran airnya. Pembangkit listrik mikrohidro kapasitas dan ketinggian aliran mengacu pada jumlah volume aliran air persatuan waktu (flow capacity). Beda ketinggian tempat dari titik pengamatan debit aliran sampai ke bangunan PLTMH dikenal dengan istilah head. Mikrohidro juga dikenal sebagai clean resources karena pembangkit listrik ini mengunakan sumber daya yang telah disediakan oleh alam dan ramah lingkungan[2], menunjukkan bahwa persyaratan utama yang harus dipertimbangkan ketika membangun pembangkit listrik tenaga mikro hidro adalah:

1. Curah hujan dan limpasan yang tersedia sepanjang waktu.

2. Memiliki ketinggian jatuh air (head)

3. Saluran air yang akan menjadi energi penggerak turbin

4. Power house sebagai rumah turbin dan peralatan pembangkit listrik lainnya

5. Saluran pembuangan air.

Debit andalan merupakan acuan potensi debit aliran sungai yang akan digunakan untuk menentukan kapasitan daya listrik dari pembangkit listrik tenaga air yang akan dibangun. Debit aliran yang dihasilkan oleh suatu hujan akan menghasilkan hidrograf yang bentuknya beragam. Keragaman bentuk 
hidrograf dipengaruhi oleh hujan dan karakteristik DAS yang meliputi keadaan penutup lahan, keadaan permukaan tanah, serta karakteristik penggal jaringan sungai. Dengan demikian bentuk hidrograf suatu sungai dapat dijadikan indikator perubahan penutup lahan dalam wilayah suatu DAS (Hadi, 2003).

Debit diperoleh dengan menggunakan rumus:

$$
Q=\mathbf{v} \cdot \mathbf{A}
$$

dimana :

$$
\begin{aligned}
Q & =\text { debit }\left(\mathrm{m}^{3} / \mathrm{det}\right) \\
\mathrm{v} & =\operatorname{kecepatan} \text { aliran }(\mathrm{m}) \\
\mathrm{A} & =\text { luas penampang basah }(\mathrm{m}) .
\end{aligned}
$$

Hubungan keeratan antara debit air dan tinggi muka air dianalisis menggunakan metode logaritma (Linsley dkk (1985).

$$
\mathbf{Q}=\mathbf{a}(\mathbf{h})^{\mathbf{b}}
$$

diamana :

$$
\begin{aligned}
& \mathrm{Q}=\text { Debit air sungai }\left(\mathrm{m}^{3} / \text { detik }\right) \\
& \mathrm{h}=\text { Tinggi muka air }(\mathrm{m}) \\
& \mathrm{a} \text { dan } \mathrm{b}=\text { Nilai kontanta }
\end{aligned}
$$

Potensi debit aliran sungai untuk sumber daya listrik dianalisis berdasarkan persamaan (Arismunandar dan Kuwahara,2000):

Dimana:

$$
\mathbf{P}=9,8 \text {. H . Q . ү́E(Kilo watt) ..(8) }
$$

$\mathrm{P}=$ tenaga yang dikeluarkan secara teoritis (Kilo watt)

$\mathrm{H}=$ tinggi jatuh air efektif (m)

$\mathrm{Q}=$ debit aliran sungai $\left(\mathrm{m}^{3} / \mathrm{s}\right)$

$\eta \mathrm{E}=$ efisiensi pembangkit

\section{METODE PENELITIAN}

Metode penelitian yang digunakan adalah metode observasi dan pengukuran lapangan. Metode observasi digunakan untuk pengukuran debit air sungai batanghari sebagai potensi tertinggi untuk menghasilkan daya listrik disekitaran jembatan aurduri II. Areal lokasi penelitiaan ditunjukan pada gambar 5. Jembatan Aurduri II - sijinjangi kota Jambi dengan posisi geografis pada koordinat $1.59,103.600219$

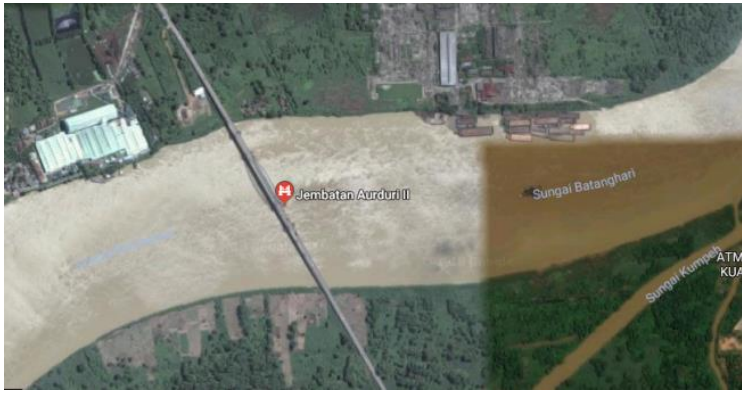

Gambar 5. Jembatan Aurduri II - sijinjang kota jambi sumber : google map

pada gambar 5. memperlihatkan luasan areal objek penelitian. Pembangkit Listrik Tenaga hybrid yang akan direncanakan dilakukan, pengukuran debit sungai setiap bulan selama 4 bulan, parameter - parameter pengukuran yang dilakukan adalah penentuan kecepatan air sungai, luas penampang basah dan kedalam air sungai dan kecepatan angin. Masing-masing pengukuran lapangan yang dilakukan adalah sebagai berikut:

\section{A. Pengukuran kecepatan Air}

Pengukuran dilakukan dikarenakan ingin mengetahui potensi kecepatan aliran sungai batanghari, pengukuran dilakukan dengan menggunakan water flow probe FP111, hasil pengukuran lapangan diperlihatkan pada tabel 1.data hasil pengukuran debit disungai batanghari dibawah.

B. Pengukuran lebar penampang basah lebar penampang pada sungai batanghari diukur dari tepian sisi sungai sampai keseberang sisi sungai, batanghari dimana pengukuran dilakukan dengan menggunakan titik kordinat pada GPS.

\section{Pengukuran kedalaman air}

Pengukuran kedalaman air yang dilakukan adalah dengan menggunakan alat ukur Digital Sonar, dimana hasil pengukuran pada sungai dilakukan dengan membagi lebar saluran menjadi 12 segment dengan lebar sungai setiap bulannya \pm 450 meter (berdasarkan lebar penampang basar) maka setiap segment adalah $\pm 40 \mathrm{~m}$.

D. Pengukuran kecepatan angin 
Pengukuran yang dilakukann menggunakan alat ukur wind speed dg81, dengan ketinggian 2 meter dari pinggiran area jembatan aurduri II sungai batanghari.

\section{HASIL DAN PEMBAHASAN}

Dari masing-masing komponen hasil pengukuran lapangan dijembatan Aurduri II Sungai Batanghari dalam perencanaan Pembangki Listrik Tenaga Hybrid diperlihatkan pada tabel 1.dibawah, dimana pengukuran dilakukan selama 4 bulan dan dalam sebulan dilakukan pengambilan data tiap minggunya.

TABEL 1. Rerata Hasil Pengukuran Lapangan

\begin{tabular}{|c|c|c|c|c|c|c|}
\hline$\stackrel{\square}{\varrho}$ & 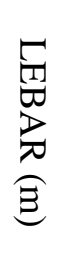 & 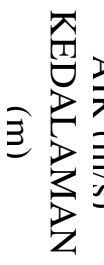 & 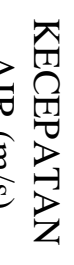 & 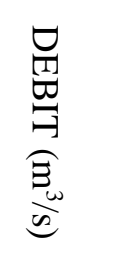 & 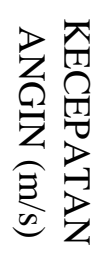 & 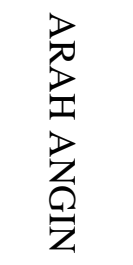 \\
\hline $\mathrm{Feb}$ & 483 & 4.3 & 1.9 & 1869.2 & 3 & \\
\hline Mar & 498 & 7.2 & 1.9 & 3227 & 3.17 & utara \\
\hline Apr & 496 & 5.9 & 2 & 2926.4 & 3.85 & barat \\
\hline Mei & 498 & 6.2 & 2.2 & 3705.5 & 4.65 & tenggar \\
\hline
\end{tabular}

\subsection{Pembangkit Listrik Tenaga Bayu}

Dari Tabel.1 diatas, distribusi angin baik arah maupun kecepatan dapat dihitung dengan menggunakan software WRPLOT View berbasis Windows yang memunculkan perhitungan wind rose dengan tampilan grafis yang menggambarkan variable meteorologi untuk rentang waktu dan tanggal sesuai kebutuhan pengguna. Wind rose menggambarkan frekuensi kejadian angin pada tiap arah mata angin dan kelas kecepatan angin pada lokasi dan waktu tertentu, perhitungan wind rose tidak selalu mewakili pergerakan riil angin di wilayah tersebut. Grafik frekuensi distribusi arah dan kecepatan angin dibuat dengan menggunakan software WRPLOT View seperti gambar 6. dibawah

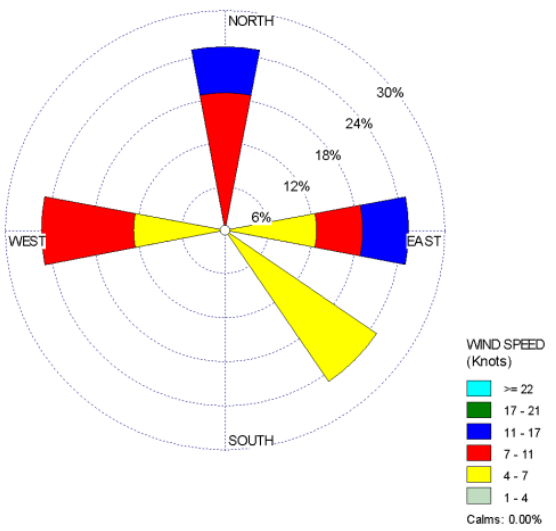

Gambar 6. Kecepatan Angin Menggunakan WRPlot

Dari hasil data pengukuran lapangan di jembatan aurduri II sungai Batanghari , frekuensi distribusi angin diperlihatkan pada gambar 7. dibawah.

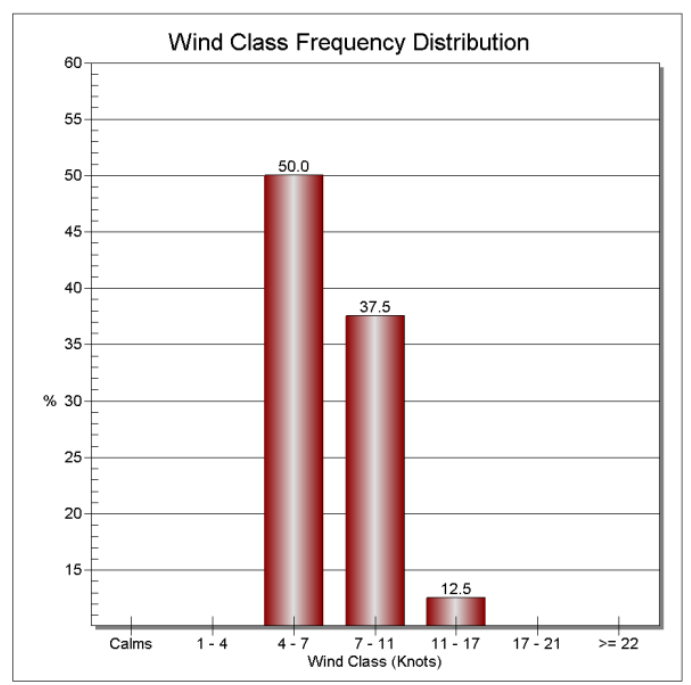

Gambar 7. Grafil Kecepatan Angin Menggunakan WRPlot

Dari persamaan 3 diatas, daya efektif yang dihasilkan kincir angin dapat dihitung dengan asumsi luas penampang balingbaling $3 \mathrm{~m}^{2}$. Hasil perhitungan diperlihatkan pada tabel 2. dibawah. 
TABEL 2. Daya Efektif Kincir Angin

\begin{tabular}{lcc}
\hline BULAN & $\begin{array}{c}\text { DAYA EFEKTIF } \\
\text { (watt) YANG } \\
\text { DIHASILKAN } \\
\text { ANGIN }\end{array}$ & $\begin{array}{c}\text { KINCIR ANGIN } \\
\text { (Ea) }\end{array}$ \\
\hline FEB & timur & 48.60419074 \\
MARET & utara & 44.12880845 \\
APRIL & barat & 76.80176652 \\
MEI & tenggara & 138.0367508 \\
\hline
\end{tabular}

\subsection{Pembangkit Listrik Tenaga Mikrohydro}

Smart Hydro Power turbin dikembangkan untuk menghasilkan jumlah maksimum daya listrik dengan energi kinetik dari air yang mengalir. Karena ia ditenagai oleh energi kinetik dan bukan energi potensial, ia dikenal sebagai turbin "zero-head" atau "in-stream". Dengan demikian, tidak ada bendungan dan / atau diferensial kepala yang diperlukan untuk pengoperasian perangkat ini; jalannya sungai tetap dalam keadaan alami dan tidak memerlukan investasi tinggi dalam infrastruktur. Karena jumlah energi kinetik (kecepatan) bervariasi dari sungai ke sungai, jumlah energi yang lebih besar dihasilkan dengan kecepatan aliran air yang lebih tinggi[7]. Teknologi eksklusif ini distandarisasikan dan mudah dalam penggunaan, produk ini diposisikan sebagai alternatif terbaik untuk elektrifikasi yang terdesentralisasi di sepanjang sungai. Turbin ini dapat diintegrasikan bersama dengan photovoltaics menjadi sistem hibrida. Kurva out put generator diperlihatkan pada gambar 8 dibawah.

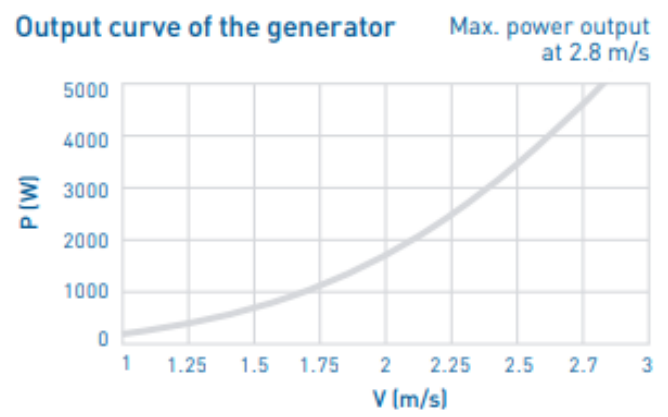

Gambar 8. Kurva Output Generator Smart Hydro Power[7]
Dari gambar diatas bila dikombinasikan dengan data lapangan yang didapat maka besar daya listrik dapat diasumsikan seperti ditunjukan pada tabel 3 dibawah

TABEL 3. Daya Efektif Yang di Hasilkan Generator

\begin{tabular}{lcc} 
BULAN & $\begin{array}{c}\text { KECEPATAN } \\
\text { AIR }(\mathrm{m} / \mathrm{s})\end{array}$ & $\begin{array}{c}\text { DAYA EFEKTIF } \\
\text { (watt) YANG } \\
\text { DIHASILKAN } \\
\text { GENERATOR }\end{array}$ \\
\hline FEB & 1,9 & 1700 \\
MARET & 1,9 & 1700 \\
APRIL & 2 & 1800 \\
MEI & 2,2 & 2100 \\
\hline
\end{tabular}

Dari tabel 3 diatas, maka dapat direpresentasikan grafik keluaran daya yang dihasilkan dari generator Smart Hydro Power seperti ditunjukan gambar 9 dibawah.

\section{OUTPUT GENERATOR)}

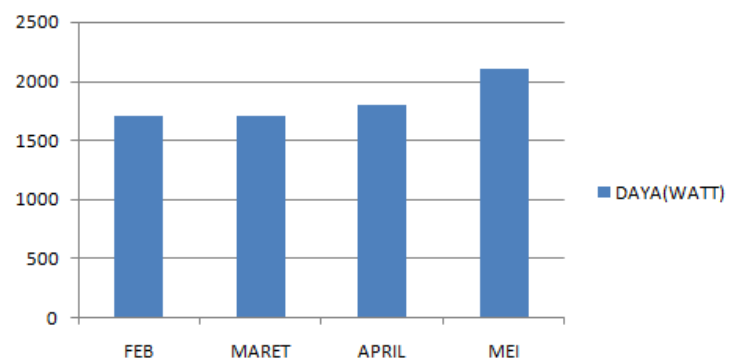

Gambar 9. Grafik Keluaran Daya Generator Smart Hydro Power

\section{SIMPULAN}

1. Analisis kapasitas pembangkitan energi listrik tenaga angin masih dapat diupayakan walau kapasitas tergolong masih kecil

2. Potensi listrik PLTMH di Jembatan Aurduri II Sungai batanghari mampu menghasilkan energi listrik yang dapat digunakan sebagai penerangan disepanjang jembatan

3. Kombinasi dari PLTB dan PLTMH disekitaran Jembatan Aurduri II dapat dijadikan Hybrid sebagai salah satu pemanfaatan energi terbarukan 


\section{DAFTAR PUSTAKA}

[1] Sardi Salim,2017, Listrik Mikro Hidro Berdasarkan Potensi Debit Andalan Sungai, Prosiding Seminar Nasional Teknik Elektro (FORTEI 2017) ISBN 978-602-6204-24-0.

[2]Douglas C.Giancoli, Physics For Scientists And Enginers, Second Edition 1988

[3]Arismunandar A., S. Kuwahara, 2000, Teknik Tenaga Listrik Jilid I: Pembangkitan dengan Tenaga Air, Pradnya Paramita, Jakarta

[4]Campbell J.R., 2010, Small Hydro and LowHead Hydro Power Technologies and Prospects, Congressional Research Service.

[5] Wilda Faradina, Hadi Suyono, ST., Mt., Ph.D., Ir. Teguh Utomo, MT., 2015, Kajian Kelayakan Ekonomis Pembangkit Listrik Tenaga Mikro Hidro Gunung Sawur 1 dan Gunung Sawur 2 Di Lumjang, Universitas Brawijaya

[6] Y.Daryanto,. Kajian Potensi Angin Untuk Pembangkit Listrik Tenaga Bayu, Yogyakarta, Balai PPTAGG.

[7] Smart Monofloat Turbine, https://smarthydro.de/wp-content/uploads/2015/12/

Datasheet_SMART_Monofloat.pdf, (diakses 15/05/2018, pukul 1.30 AM) 